\title{
POP Culture: Interaction of and Influence on the
}

\section{Youth}

\section{Tippabhotla Vyomakesisri ${ }^{1}$, Thigulla Sonu ${ }^{2}$, Doballi Srikanth ${ }^{3}$}

${ }^{1}$ MA English, Research Scholar, Osmania University, Hyderabad, India

${ }^{2,3}$ B.com (Comp) II yr, St. Joseph's Degree and PG College, Hyderabad, India

\begin{abstract}
In today's world of digital literacy's, popular culture is considered to be a 'central force.' It has made inroads into our lives like nothing else has. The 21st century popular culture significantly changed our ways of life and impacted it and has transcended the barriers of age, gender, class, color, religion etc. and has become a part of our daily patterns and its impact on the society is best seen and felt among the youth. It is understood that the youngsters of any era are most susceptible to changes brought by the society. The $2000 \mathrm{~s}$ has brought in a new hang-out place for the educated mass - online venues. The advent of computers, internet and the World Wide Web has led to tremendous advancement in technology and thus we are able to access all kinds of documents, databases, bulletin boards, electronic publications like newspapers, books and magazines in all media forms (print, audio-oral, visual) via internet and can create our web pages to publish individual art, writings, videos, movies, etc. on popular websites or on personal blogs. Popular culture is irrefutably connected with commercial culture like movies, television, radio, cyberspace, advertising, fashion etc that is available for online purchase.

The popular culture, which is very popular with the youth, and their aggressive indulgence in the social media, mass media and other media like mobile phones, English cinema and English music, this paper examines and understands the ways by which popular culture forms can be used.This study looks at how popular cultural forms like internet, social networking sites, television, popular music, cinema, newspapers, magazines etc. Influenced the language of today's youth and in this process a 'new' language style is emerging among them.

If we look back to the $20 \mathrm{C}$, we find that various youth identities have emerged, with their unique styles in music, dance, clothing, hairstyle and language, assisted by the corresponding progress of the mass media and the interactive digital media such as the internet. In the midst of such cultural dynamism, language undeniably takes a new form used in communication that is mediated through numerous agencies. With the mushrooming of television channels, social networking sites, blogs, music and film genres, video and computer games etc. the youth of today's generation lives a life that is completely dominated by technology and pop culture. The pressure to fit into the group, be one in the crowd, is so overpowering for the youngsters today that most of them live their lives dictated as seen in movies, TV serials, and fashion tips from popular magazines.
\end{abstract}

Keywords - Culture, Pop culture, mass media, social networking sites, cyberspace, baby boomers, slang, 'going viral'.

\section{INTRODUCTION}

Culture Defined:

Culture is the characteristics and knowledge of a particular group of people that encompasses language, religion, cuisine, social habits, music and arts.

The Center for Advance Research on Language Acquisition defines culture as shared patterns of behaviors and interactions, cognitive constructs and understanding that are learned by socialization. Thus, it can be seen as the growth of a group identity fostered by social patterns unique to the group.

"Culture encompasses religion, food, what we wear, how we wear it, our language, marriage, music, what we believe is right or wrong, how we sit at the table, how we greet visitors, how we behave with loved ones, and a million other things," Cristina De Rossi, an anthropologist at Barnet and Southgate College in London, told Live Science. 
The word "culture" derives from a French term, which in turn derives from the Latin "colere," which means to tend to the earth and grow, or cultivation and nurture. "It shares its etymology with a number of other words related to actively fostering growth," De Rossi said.

\section{Constant Change:}

No matter what culture people belong to, one thing is for certain that it will change because Culture has become a key to our interconnected world, that is made up of so many ethnically diverse societies, conflicts associated with religion, ethnicity, ethical beliefs, and, essentially, the elements which make up culture," De Rossi said. "But culture is no longer fixed, if it ever was. It is essentially fluid and constantly in motion." This makes it so that it is difficult to define any culture in only one way.

\section{POP CULTURE}

Popular culture is everywhere for eg. Listen to music, watch television, app-gaming or go to a movie, concert or stage shows, sports personalities and the games they play all are deemed to be a part of the pop culture. Pop culture is therefore defined as a collection of thoughts, ideas, attitudes, perspectives, images (you name it) preferred by the mainstream population a kind of common denominator.

Various pop culture categories are: entertainment (movies, music, TV), sports, news (as in people/places in news), politics, fashion/clothes and technology. Slang, is a prominent form of pop culture, especially with teens. Terms such as "going viral" are already viral now.

Each one of us has our own pop culture menu like our customized apps, bookmarks, song playlists, TV shows, movies, smartphones, net-flix and you tube videos, sports. Smart phones today are the center of the pop culture.

Although not used in our lexicon back then - modern pop culture began with the baby boomer generation and "buying power." The disposable incomes of the boomer generation had influenced and led the pop culture revolution that began during the 1950's with rock and roll, TV, transistor radios etc. and slowly progressed beyond $1960 \mathrm{~s}$.

The term "pop culture" has become a mainstream term during the 1980's. Before this, we used the word "popular" to describe things such as, top song playlists or "pop" as in art or "best" or "top" selling, as in books.

Pop culture is fun, fascinating and is at the center of our lives.

\section{Youtube}

The Decade which bought an immense revolution in Socializing people through various new platforms and giving opportunities to everyone to show their talents and one such platform is YouTube.

YouTube was launched way back in the year 2005 and it was taken over by Google in the year 2006. The platform allows various artists to show their talents, to spread awareness, to educate and to get educated, to show the world the unseen things and make lives better and better everyday. There are creators who create content in form of videos and viewers who watch them to attain some knowledge.

The platform has had a great impact on the youth and the people of India. YouTube has a vast amount of pop content on its site, and their are many creators who paved way for many people out there.

Vloging was never a thing in India until YouTube showed up. Big creator's like PewDiePie who inspired a lot of Indian vlogger like Mumbiker Nikhil.

The tech YouTubers in India are growing day by day and the famous YouTubers have learned a lot from the Western YouTubers like MKBHD. Indian have always done things differently, it is true that pop culture has inspired us a lot but as our Indian YouTubers who adapted and improvised are reaching greater heights than the likes of Pop YouTubers. One of the greatest milestones can be of Technical guruji who creates Tech related videos and has a strong subscriber base of 14 Million+.

YouTube has made life easier and Indian have utilized it in a efficient way to show their art, talent and share their knowledge.

\section{Food}

As this whole world is becoming smaller and smaller day by day due to globalization various cultures have their footprints everywhere around the world.

One such aspect which has its footprints almost in every country is Food. India has its own variety of cuisines and delicious dishes but lately the western culture has hit the Indian culture and changed many food habits of the people.

Remember when was the last time you ate with your bare hands? Exactly its been a while isn't it?

Well eating with hand has its marks since the Vedic age but nowadays that's not the case we all love to eat with spoons or food which is wrapped in tissues and God knows what kind of plastic covers. Our food habits have changed but it has its own positives and negatives, change is the rule of life some are for good reasons and few which are unnecessary.

Fast food centres have taken India by storm 
From late 2000s India has seen a whopping rise in fast food centres and people are going nuts for such restaurants.

Companies like McDonald's, Domino's, KFC and burger king have a huge fanbase and they earn a lot of profit's from Indian market.

McDonald's has its own variety of food segment targeted for breakfast, lunch and dinner because of which it has become a go to place for the people in India on a large scale. Domino's offers delicious pizza like no other company and it is one of the favorites among the people.

The western food is full of nutrition and fats and but at the same time it is what we call junk food which is the main reason for many kinds of diseases.

\section{Music}

The Indian classical music is undoubtedly a masterpiece and one of its kinds which has influenced the whole world with its unique and soothing touch.

Indian music is very vast and spread across many languages. But somewhere our music has hit the western trend as well; artists from across the world are collaborating with Indian musicians and creating content which has never been seen before.

Rapping has become a new trend, 2019 also saw a movie which was completely dedicated to rapping.

Big events are taking place which is a direct influence of western culture, crowd is going crazy just to get the tickets of the show and have a glimpse of their favorite artists.

The western music has its impact on various platforms may it be movies, advertisement or music albums everything nowadays has a touch of western music with Indian music.

Great artists like A R Rahman are collaborating with Westerner musicians to create wonders and so far it has been successful.

Many new instruments are being used by Indian musicians and they are creating music of India and attracting the youth around the world.

Indian musicians have a worldwide fame due to their uniqueness and music never heard before.

The Indian music is growing day by day without losing its roots yet growing and reaching greater heights with the help of western culture.

\section{Movies}

The Bollywood has been in the hearts of Indians since the beginning. It's not just movies for the country it's a diverse culture which is none less than a festival when it comes to big star's like Rajnikanth, sharukh and Salman.

The celebrities and the industry itself has earned huge respect and fame across the world but it's very root's have a touch of
Western Films, the industry's name Bollywood is a rip off of Hollywood.

In the very beginning the movie were subtle and were filled with the tradition and cultures of India as decade's passed by the Indian film industry saw a huge influence of western culture one of the biggest changes which western culture bought was in fashion. Star's came up with western styles in movies which were loved by the crowd on big scale.

Actors started wearing Jeans and T-shirts and Actresses instead of saree and salwar changed the fashion completely to tight one Piece dresses.

The movie filming styles also changed like Western culture the dance had a huge impact on the industry, directors and producers demanded for big budget video songs in the movie because it attracted the public.

Lately many movies also introduced English songs in Hindi movies.

Movies instead of showing family drama started showing content which had a social message and bought a difference in viewer's mentality and life.

Western culture has certainly made the Indian film industry better but the question lies in that is our culture still alive? Do you see bharatnatyam and katakali in movies? Very rare and this itself shows that somewhere we are losing our traditions and cultures.

Bahubali and bajirao mastani are movie's which set an example for showing tradition and Puranas of our heritage and if other producers follow there footprints then Indian Industry has a lot to Dig into the History of India and show it to the world out there.

\section{Influence of Smartphone}

Today people have new addictions known as smartphone addiction. The Smartphone of today have so many feature that the owners of them can hardly seem to put them down just for a second. These smartphones not only offer few features that a personal computer would, but also provide a very high level of entertainment to people with busy work schedules and personal pre- occupations. Therefore their priority is to own a mobile device that satisfies their needs to stay in touch and be reachable at anytime. A Smart phone therefore allows its users to communicate and exchange information such as texts, documents, pictures, and videos through internet or mobile networks. Smart phones redefined the term multitasking with huge powerful applications and allow its users to work and extend their social connections in many ways.

A slogan for all smart phones users 'your life in your pocket', attracts them to these devices that has many useful 
features. Further than that, the latest generation of smart phones have provided social applications and powerful entertaining functions to everyone who love social network. In fact, today more people like to connect to their friends through social networking sites as a result they have become a trend in online communication. Therefore, Facebook, Myspace, Twitter and whats app apps have became a mandatory requirement for people thus becoming a social necessity and a status symbol. Smartphone shopping has become easy. Because of this people are tending to become lethargic.There is no doubt that smartphones have made our lives better but even they do have a lot negative impact. The first impact is the emission of radiation which may cause serious damage to human health. The interaction between people is declining day by day. Relations are getting affected everything is done using a smartphone. Sexual soliciting through smartphones has become a major negative impact. Smartphones are taking away today's youth. This is one of the reasons for decline in lifespan of human beings.

\section{Influence of Western clothing}

Western attire adoption has become a rage now all over the globe. The influence of western clothing on people around the world is incredible and there are many different reasons for this influence, one of them being western clothing seen as a modern form of dressing when compared to traditional clothing.

The factors that led to this western form of dressing is industrialization and the development of leading countries in the world that made their dressing mainstream. Japan, adopted successful western societies in not just policy but culture and clothing as well.

Language like English found its way to becoming a spoken language and is understood as the standard world over. In the same way, western clothing started finding its way into the everyday lives of the people that started very early during the colonial era where the colonizers brought drastic cultural changes to their colonies, which included western clothing as well. Being the dominant culture, their impact was fast and long lasting and no sooner it has become a status symbol in many societies.

This also has roots in the colonial era, when looking like the colonizer was considered a sign of affluence and influence. The colonizers themselves encouraged this trend as well.

Even now, dressing up in western clothing is a considered as a sign of good fortune, quality education and financial status in many societies. In many regions of the world, western attire can increase a person's chances of success in the society.

Western clothing is considered as modern form of clothing because it is considered relatively new when compared to more traditional fashion and cultures. It is also very often considered as gender neutral.

Western clothing has become more popular and mainstream because of the western music, literature and arts where only the western clothing was used and it also influenced people all around the world thus taking over all the traditions.

\section{Netflix}

Netflix is one of the areas which is drawing in binge watchers from all over the world and potentially distracting them from their everyday tasks.

People justify spending time in the evening in front of a television or computer for many reasons. A lot of people want to relieve stress from a hard day at work or just take some time to slow down for the night. Everybody with a Netflix account can sit down in front of the television, start watching a series and escape from reality by then hours and hours have gone by and the one episode that was intended to be watched has now become many episodes thereby people losing track of time while watching series and television shows that is now being called the "Netflix Effect." The curiosity of people to find out what next happens in a series or a show glues them to watch endlessly having no conscious of the time. This hanging effect creates a need to find out what happens next. After hours and hours have passed sitting in front of a television or computer, some households are now asking whether or not watching Netflix is really a positive way to relieve stress or if it is actually taking up most of their free time. According to reports, teens, adults, and even children are being impacted by the "Netflix Effect." The disadvantages for teens who binge watch television include slipping grades, being late to work or class, not going outside to be active thereby gaining weight, and closing themselves off from having a social life.

Online video streaming and Netflix are an instant hit among college crowds. There are some people who sit late nights and watch shows on Netflix. The term they use in doing this 'Netflix and chill'. There is no real definition for this but what they do is invite someone of the opposite sex over, pick a random show from Netflix, start watching the show, and then make out with your date while the episode after episode plays in the background.

Netflix has become a new addiction. This new idea of binge watching television or online series is robbing people of valuable time that they can never get back. Households these 
days are dealing with the "Netflix Effect", while colleges deal with the "Netflix and Chill" concept of dating. Watching Netflix is not always bad. Netflix can also be a good stress reliever and can create family fun time. It is a great source for watching movies or even catching up on some of favorite shows. The challenge is about finding enough self control to create a healthy balance between relaxation and wasting time.

\section{CONCLUSION}

Popular culture influences an individual's attitudes towards certain topics and as a result of this, it has both positive and negative impacts on the lives of youth and in their capacity to contribute to societal development. For one, popular culture strengthens interactions between people with the same likes and dislikes. It also provides youth with an outlet for them to express themselves and share their feelings and opinions among themselves. Popular culture enables youths to be more creative and to expand their horizon, helping them to explore and expand their identity.

The emergence of popular culture in a globalized world has become indispensable in our society owing to the rise of new technology. Popular culture has become a part and parcel of everybody's life as it is connected with education, mass communication, and production and how it has become the main tool through which youth learn about themselves, society and the larger world. Despite the positive effects of popular culture on society; it can also has disastrous consequences on youth when they are not properly particularly the new/mass media.

Popular culture strengthens interactions between people with the same likes and dislikes. It also provides youth with an outlet for them to express themselves and share their feelings and opinions among themselves. Popular culture enables youth to be more creative and to expand their horizon, helping them to explore and expand their identity.

\section{REFERENCES}

[1] https://www.researchgate.net/publication/332531218 Youth and_Popular_Culture_Popular_Culture_and_Youth_Capacity for_Societal_Development_in_Nigeria/link/5cba4b32458515 6cd7a477cb/download

[2] https://medium.com/@ fshareef345/western-influence-onbollywood-b293580045ba

[3] https://dhvaniohio.org/western-influence-on-indian-music/

[4] http://www.swarnimbharat.com/western-food-hit-indiankitchens-pros-cons/

[5] https://en.m.wikipedia.org/wiki/PewDiePie
[6] https://www.keyideasinfotech.com/blog/impact-ofsmartphone-on-societyl

[7] https://depts.washington.edu/chinaciv/clothing/t20cdev.htm

[8] https://www.iknockfashion.com/evolution-of-eastern-andwestern-style/

[9] https://www.jordan-clark.com/influence-of-western-clothing/

[10] https://medium.com/@ 10805833/netflix-and-its-impact-onsociety-8357bcb96a22

[11] https://www.livescience.com/21478-what-is-culturedefinition-of-culture.html

[12] www.dailyhudson.com/what-is-culture 